\title{
PENERAPAN MODEL VCT (VALUE CLARIFICATION TECHNIQUE) DALAM PEMBELAJARAN MENULIS ARGUMENTASI DI ERA SOCIETY 5.0
}

\author{
Ulfah Nurzulfa Setiadi ${ }^{1}$ dan Andoyo Sastromiharjo ${ }^{2}$ \\ SMA Negeri 1 Cisarua, Kabupaten Bandung Barat ${ }^{1}$ \\ Universitas Pendidikan Indonesia ${ }^{2}$ \\ Surel: ulfahsetiadi95@gmail.com ${ }^{1}$ \\ andoyo@upi.edu ${ }^{2}$
}

\begin{abstract}
Abstrak
Penelitian ini bertujuan untuk mengetahui perbedaan skor afektif dan psikomotorik siswa yang menggunakan model pembelajaran konvensional dan model pembelajaran Value Clarification Technology (VCT) pada pembelajaran menulis argumentasi kelas X SMA Negeri 1 Cisarua tahun pelajaran 2020/2021. Jenis penelitian ini adalah penelitian eksperimental semu, dan jumlah seluruh siswa kelas $\mathrm{X}$ adalah 30 orang. Hasil yang diperoleh adalah 1) tidak terdapat perbedaan hasil belajar afektif dan psikomotorik yang signifikan pengukuran awal antara kelas eksperimen dan kelas kontrol. Hasil analisis menunjukkan bahwa nilai thitung lebih kecil dari nilai $t_{\text {tabel }}(1,102<1,767)$ yang artinya tidak terdapat perbedaan yang signifikan; 2) terdapat perbedaan hasil belajar afektif menulis argumentasi yang signifikan dengan pengukuran akhir antara kelas eksperimen dan kelas kontrol terlihat dari hasil rata-rata pengukuran awal kelas eksperimen. Hasil analisis menunjukan bahwa nilai $\mathrm{t}_{\text {hitung }}$ lebih kecil dari $\mathrm{t}_{\text {tabel }}(2,910>2,013)$ yang artinya terdapat perbedaan yang signifikan; 3) terdapat perbedaan hasil belajar psikomotorik menulis argumentasi yang signifikan dengan pengukuran akhir antara kelas eksperimen dan kelas kontrol terlihat dari hasil rata-rata pengukuran awal kelas eksperimen. Hasil analisis menunjukan bahwa nilai thitung lebih kecil dari $t_{\text {tabel }}(3,714$ > 2,000) yang artinya terdapat perbedaan yang signifikan; dan 4) respon siswa terhadap model pembelajaran VCT (Value Clarifiction Technique) dapat dikatakan sangat baik, dilihat dari hasil perhitungan secara keseluruhan adalah sebesar 94,25\%.

\section{Jurnallimiah}

Kata Kunci: model VCT (ValuedClarificationDTechnique), menulis argumentasi, dan society 5.0

\section{Abstract}

This study aims to find out the difference between affective and psychomotor scores of students using conventional learning models and Value Clarification Technology (VCT) learning models in the learning of writing argumentation grade X SMA Negeri 1 Cisarua in the 2020/2021 school year. This type of research is quasi experimental research, and the total number of first grader is 30 people. The results obtained were 1) there was no significant difference in affective and psychomotor learning outcomes of initial measurements between the experimental class and the 
control class. The results of the analysis showed that the calculated t value was less than the table $t$ value $(1,102<1.767)$ which meant there was no significant difference; 2) there was a significant difference in affective learning outcomes writing arguments with the final measurement between the experimental class and the control class seen from the average results of the initial measurement of the experimental class. The results of the analysis showed that the calculated t value is smaller than the table $t(2,910>2.013)$ which means there is a significant difference; 3) there is a significant difference in psychomotor learning outcomes writing arguments with the final measurement between the experimental class and the control class seen from the average results of the initial measurement of the experimental class. The results showed that the calculated $t$ value is less than the table $t$ (3,714 >2,000) which means there is a significant difference; and 4) The student's response to the VCT (Value Clarifiction Technique) learning model can be said to be very good, judging from the overall calculation result of $94.25 \%$.

Keywords: VCT (Value Clarification Technique) model, argumentation writing, and society 5.0

\section{PENDAHULUAN}

Pendidikan memainkan peran yang sangat penting dalam meningkatkan kualitas sumber daya dalam tingkat kehidupan sosial yang terus berkembang pada masyarakat global. Selain itu, kondisi kehidupan di abad 21 sangat menantang dan kompetitif. Hal ini antara lain juga berdampak besar pada kita khususnya pendidik dan peserta didik yang dituntut untuk dapat memiliki kompetensi hidup dan kemampuan multiliterasi sehinga dapat memanfaatkan kesempatan ini untuk meningkatkan kemampuan fisik, mental, dan intelektual.

Jurnal Ilmichenghadapi tantangan Society 5.0?

Globalisasi telah memberikan pengaruh yang beragam di Indonesia. Dalam setiap persoalan globalisasi, dampak positif dan negatif terus bermunculan. Di bawah pengaruh globalisasi, setiap orang perlu berpikir lebih kritis dan kreatif untuk menghadapi berbagai dampak yang ditimbulkan oleh globalisasi. Kemajuan globalisasi saat ini sudah bukan lagi dengan Revolusi Industri 4.0, namun datangnya Society 5.0. membuat kita

terus tiada henti untuk mengejar arus perkembangan zaman globalisasi.

Dalam perkembangan masyarakat internasional global yang berkelanjutan, pendidikan memegang peranan yang sangat penting dalam meningkatkan kualitas sumber daya. Dengan menggabungkan berbagai teknologi untuk mereduksi pembatas antara dunia fisik, digital dan biologis, telah terjadi perubahan yang luar biasa di berbagai bidang. Pada saat yang bersamaan, Society 5.0 bisa dikatakan sebagai masyarakat yang super pintar. Pertanyaannya adalah dapatkah pendidikan di Indonesia siap diprakarsai oleh pemerintah Jepang. Konsep masyarakat yang berorientasi pada manusia dan berbasis teknologi. Dalam konsep Society 5.0, umat manusia akan memainkan peran yang lebih besar dengan mentransformasikan big data menjadi kearifan, dan akhirnya membuka peluang bagi umat manusia untuk mewujudkan kehidupan yang lebih bermakna. Sehingga, masyarakat 
dapat lebih bijaksana dalam menggunakan sebuah teknologi.

Dengan pesatnya perkembangan teknologi informasi, diharapkan pendidikan dapat meningkatkan daya saing bangsa dalam persaingan global. Namun, tidak dapat dipungkiri bahwa saat ini masih banyak masyarakat yang kurang memahami dunia digital, dan berbagai penyalahgunaan media digital telah terjadi di tingkat individu, sosial dan nasional. Oleh karena itu, peningkatan kualitas pembelajaran menjadi salah satu tantangan bagi peserta didik.

Inti dari pendidikan adalah kurikulum. Kurikulum tidak hanya berisi ungkapan tentang konten dan kegiatan pembelajaran, tetapi juga menentukan tempat di mana peserta didik akan dibawa dan dibimbing dengan nilai pengetahuan dan sikap (Purnamasari, Yunisulul, dan Desyandri, 2018: 11-24). Pembelajaran bahasa Indonesia dalam Kurikulum 2013, dimaksudkan untuk membina dan mengembangkan kepercayaan diri peserta didik sebagai komunikator, pemikir imajinatif, dan warga negara Indonesia yang melek literasi dan informasi (Kemendikbud, 2016: 1). Sejalan dengan tujuan kurikulum 2013 yang disebutkan di atas, literasi dan menulis sangat erat kaitannya. Jurnal I

Menulis adalah kegiatan mengubah ide atau konsep menjadi simbol yang dapat dibaca dan dipahami oleh orang lain. Kegiatan menulis merupakan manifestasi dari keterampilan berbahasa yang diperoleh pembelajar bahasa setelah menyimak, berbicara, dan membaca (Nurgiyantoro, 2001: 296). Selain itu, Nurgiyantoro juga mengemukakan bahwa dibandingkan dengan kemampuan bahasa lainnya, pembelajar bahasa lebih sulit menguasai keterampilan menulis. Hal ini dikarenakan keterampilan berbahasa membutuhkan penguasaan semua aspek selain bahasa agar menghasilkan komposisi yang kokoh dan lengkap.

Berdasarkan pengertian menulis di atas, dapat disimpulkan bahwa menulis adalah kegiatan yang mengubah ide atau konsep menjadi simbol yang dapat dibaca dan dipahami oleh orang lain.

Selain sebagai keterampilan berbahasa, menulis juga merupakan proses pembelajaran penalaran (Akhadiah, Arsyad, dan Ridwan, 1988: 41). Penalaran adalah proses berpikir sistematis, menarik kesimpulan dalam bentuk pengetahuan. Dalam menulis, kemampuan berpikir seseorang haruslah sangat tinggi, karena suatu ide akan muncul melalui pemikiran. Tidak mudah untuk mengungkapkan satu atau lebih ide.

Pandangan Suriasumantri lebih jauh membuktikan hal tersebut, yaitu bahasa adalah alat komunikasi ekspresif yang digunakan untuk menyampaikan perasaan, keinginan atau sikap. Bahasa juga adalah alat komunikasi argumentatif yang digunakan untuk berkomunikasi dengan jalan pikiran yang melatarbelakangi pemikiran tersebut. Selain itu, aspek bahasa yang bersifat arugmentatif sering digunakan dalam komunikasi ilmiah (Suriasumantri, 1996: 120).

Jenis tulisan yang dapat dikembangkan untuk kepentingan di atas adalah penulisan argumentatif. Argumentasi adalah karangan yang membuktikan kebenaran atau ketidakbenaran suatu pernyataan. Secara tradisional, teks argumentasi dibagi menjadi dua kategori, yaitu induksi dan deduksi.

Dalam sebuah argumen, penulis dapat memilih salah satunya, atau sering 
menggunakan keduanya. Dalam teks argumen, penulis menggunakan berbagai strategi atau alat retoris untuk membuat pembaca percaya ihwal kebenaran atau ketidakbenaran. Penalaran induktif menarik kesimpulan berdasarkan banyak bukti, sedangkan penalaran deduktif menggunakan faktafakta umum untuk mendukung kebenaran.

Untuk meningkatkan kemampuan menulis argumen diperlukan proses berpikir kritis. Hal ini karena berpikir merupakan aktivitas yang menentukan dalam memecahkan masalah. Selain itu, kegiatan menulis argumentasi dapat membantu peserta didik meningkatkan dalam mengembangkan pemikirannya. Bagi peserta didik, keterampilan berbahasa yang sangat cocok untuk dikembangkan melalui metakognisi dan berpikir kritis adalah keterampilan menulis. Hal ini dikarenakan tulisan mengandung masalah yang timbul, dan kesimpulan yang dapat diambil dari data yang dianalisis, diolah atau dibahas mengenai masalah tersebut (Widyamertaya dan Sediati, 1997: 87). Menulis juga dapat mempertajam pikiran melalui keterampilan analitis dan interpretasi data yang diperoleh dari contoh-contoh yang dipertimbangkan dengan cermat (Hernowo, 2001: 116).

UNESCO (2003) berpandangan bahwa masyarakat global yang harus mampu beradaptasi dengan kemajuan teknologi, mengetahui perkembangan terkini. Pemerintah mencanangkan pentingnya literasi informasi yaitu kemampuan mencari, memahami, mengevaluasi secara kritis dan mentransformasikan informasi menjadi pengetahuan yang sangat berguna bagi perkembangan kehidupan pribadi dan sosialnya. Tentunya hal ini menuntut setiap orang untuk berpikir lebih serius dari sebelumnya.

Secara teknis penguatan pendidikan dilaksanakan dengan menggunakan kemampuan abad 21, dan yang terpenting mampu melaksanakan 4C yaitu kemampuan berpikir kritis, kreativitas, kolaborasi dan komunikasi, serta keterampilan berpikir tingkat tinggi. Era persaingan global saat ini menuntut pembelajaran yang berkualitas untuk memberikan fasilitas kepada peserta didik dalam mengembangkan keterampilan, dan kemampuan sebagai modal untuk menghadapi tantangan kehidupan global (Daryanto dan Karim, 2017: 137) .

Menurut beberapa jurnal penelitian yang diulas oleh peneliti, beberapa permasalahan masih sering muncul dalam proses pengajaran. Menurut data penelitian yang dilakukan oleh Nasia, Saneba, dan Hasdin, terdapat beberapa permasalahan dalam proses pembelajaran, antara lain tidak pernah melaksanakan pembelajaran atas dasar penanaman nilai untuk membentuk sense of value peserta didik, kurangnya sumber daya buku terkait pembelajaran nilai, dan kurangnya penerapan model pembelajaran nilai bagi peserta didik (Nasia, Saneba, dan Hasdin, 2014:64).

Jika melihat dari fenomena tersebut seakan-akan proses pembelajaran hanya sekedar rah mentransformasikan pengetahuan saja. Guru hanya menyampaikan inti materi dari mulai pengertian, struktur, kaidah kebahasaan dan sebagainya tanpa memberikan nilainilai apa saja yang ada serta alasan dan manfaat peserta didik mempelajari materi tersebut.

Tujuan pembelajaran bahasa Indonesia di sekolah tidak hanya berkaitan dengan kemampuan siswa dalam menguasai materi berbagai teks 
yang disajikan. Guru harus tetap memperhatikan aspek afektif dan psikomotorik. Namun, hal ini justru seringkali dilupakan guru dalam proses pembelajaran. Selama ini praktik pembelajaran bahasa Indonesia di sekolah masih cenderung pada proses transmisi informasi. Meskipun suasana pembelajaran yang dirancang oleh guru menuntut peserta didik untuk berperan aktif, semua itu hanya terkait dengan penguasaan kemampuan dalam ranah kognitif saja.

Pembelajaran bahasa Indonesia yang dirancang belum mencapai kebermaknaan dan kepraktisan-nya dalam kehidupan sehari-hari. Sehingga pendidikan di Indonesia seakan-akan masih mengedepankan pengetahuan kognitif, bukan semangat, sikap dan keterampilan. Selain itu, pembelajaran masih menggunakan model yang berpusat pada guru. Pemerintah dan sekolah sendiri pun kurang menitikberatkan pada penanaman nilai moral, pembelajaran berbasis nilai belum banyak diterapkan, dan guru jarang atau tidak pernah menggunakan model pembelajaran berbasis nilai sehinga guru hanya fokus kepada hasil kognitif dari peserta didik (Rejeki, Sri, dan Ganes Gunansyah, 2015:100).

Sanjaya mengungkapkan bahwa klarifikasi nilai (biasa disebut dengan VCT) diartikan sebagai model pembelajaran yang dirancang untuk membantu siswa menemukan dan menentukan nilai yang dapat menyelesaikan masalah dengan baik dengan mengembangkan dan menganalisis nilai yang tertanam di dalamnya (Sanjaya, 2006: 92).

Tahun 1950-an, Louis Raths pertama kali menggunakan model pembelajaran VCT (Value Clarification Technique) ketika ia mengajar di
Universitas New York. Model Pembelajaran VCT ini dapat membantu siswa menentukan nilai atau makna secara mendalam. Model pembelajaran VCT dapat membantu peserta didik menemukan dan menentukan nilai apa yang dianggap yang baik. Ini merupakan metode pendidikan nilai dimana siswa dapat menemukan, memilih, menganalisis, memutuskan, mengadopsi nilai-nilai kehidupannya sendiri, dan mengembangkan sikap selama proses berlangsung (Etin, 2014: 91-93).

Model pembelajaran VCT juga dapat diterapkan melalui diskusi, dialog dan pernyataan untuk mengemukakan masalah-masalah yang ada di lingkungan sekitarnya, merumuskan nilai-nilai mereka sesuai dengan pilihannya, dan melalui bimbingan untuk mengetahui makna dari nilai masalah tersebut, sehingga dapat dipelajari. Manfaat VCT adalah melatih dan mengembangkan peserta didik dalam proses evaluasi terhadap nilainilai yang ada dan berkembang di masyarakat, serta mampu menentukan dan memilih nilai-nilai tersebut sebagai acuan hidup mereka (Adisusilo, 2012: 56).

Model pembelajaran VCT pada dasarnya bersifat induktif, berasal dari pengalaman-pengalaman peserta didik yang akhirnya memunculkan ide-ide umum tentang pengetahuan dan kesadaran diri. Sederhananya, guru dapat membimbing siswa untuk belajar dalam kelompok, kemudian peserta didik dapat membandingkan dengan pengalamannya. Guru berperan dalam membantu siswa memahami nilai-nilai yang dimilikinya.

Hal ini serupa dengan yang diyakini oleh Taniredja bahwa VCT memiliki lima prinsip, yaitu: a) 
Penanaman nilai dan perubahan sikap dipengaruhi oleh banyak faktor, antara lain faktor potensi diri, kepekaan emosional, faktor intelektual dan lingkungan, norma nilai masyarakat, sistem pendidikan, lingkungan keluarga dan lingkungan bermain; b) Perubahan sikap dipengaruhi oleh stimulus yang diterima peserta didik dan kekuatan nilai yang tertanam atau dimiliki peserta didik; c) Nilai, etika dan norma dipengaruhi oleh faktor perkembangan, sehingga guru harus mempertimbangkan tingkat perkembangan moral setiap peserta didik. Tingkat perkembangan moral peserta didik dipengaruhi oleh usia dan lingkungan, terutama lingkungan sosial. d) Perubahan sikap dan nilai memerlukan klarifikasi terhadap nilai dan sikap secara rasional, sehingga kesadaran diri pada diri peserta didik bukan karena adanya rasa kewajiban atau tindakan tertentu; e) Perubahan suatu nilai membutuhkan keterbukaan, sehingga pembelajaran melalui VCT ini membutuhkan keterbukaan antar guru dan peserta didik (Taniredja, 2011: 89). Menurut Hall dalam Adisusilo, (2013:1. $\quad$ Memilih 95) model pembelajaran Value Clarification Technology (VCT) adalah

“...by value clarification we mean a methodology or processingy which we help a person to discover Procerver ${ }_{\text {sia }}$ dan Daerah ideas, and through important choices he has made and is continually, in fact, acting upon in and through his life..."

Pandangan ini memiliki makna bahwa klarifikasi nilai adalah metode atau proses yang dapat membantu orang menemukan nilai melalui perilaku, perasaan, gagasan, dan pilihan penting yang telah mereka buat dan terus buat, lalu mempraktikkannya dalam kehidupan sehari-hari. Dalam kesempatan yang sama. Maka dari itu, sesuai dengan pendapat beberapa para ahli, dapat disimpulkan bahwa Value Clarification Technology (VCT) merupakan cara menanamkan nilai pada siswa, menggali atau mengungkapkan nilai-nilai tertentu siswa.

Metode pembelajaran VCT merupakan proses yang membantu siswa menanamkan nilai melalui ekspresi perilaku, perasaan, ide dan nilai secara terus menerus.

Proses klarifikasi nilai menjadi tiga nilai menurut model pembelajaran VCT. Dalam ketiga proses tersebut terdapat tujuh subproses, seperti yang ditunjukkan pada tabel berikut.

\section{Tabel 1}

Proses Klarifikasi Nilai

\section{Berdasarkan dari Penilaian Afektif pada Pembelajaran Menulis Argumentasi}

\begin{tabular}{|c|c|}
\hline & ra bebas \\
\hline & $\begin{array}{l}\text { Memilih dengan berbagai } \\
\text { opsi/pilihan }\end{array}$ \\
\hline & $\begin{array}{l}\text { Memilih dengan berbagai opsi } \\
\text { setelah melewati } \\
\text { pertimbangan tentang } \\
\text { berbagai dampak yang akan } \\
\text { ditimbulkan }\end{array}$ \\
\hline & $\begin{array}{l}\text { Menghargai dan merasa benar } \\
\text { terhadap apa yang dipilih }\end{array}$ \\
\hline Dia. & $\begin{array}{l}\text { Berpegang teguh pada } \\
\text { pilihannya }\end{array}$ \\
\hline Bertindak & $\begin{array}{l}\begin{array}{l}\text { Bersikap } \\
\text { pilihannya }\end{array} \\
\text { sesuai dengan }\end{array}$ \\
\hline & $\begin{array}{l}\text { Menerapkan kebiasaan sesuai } \\
\text { berdasarkan pilihannya. }\end{array}$ \\
\hline
\end{tabular}

Sumber: Hall dalam Adisusilo, (2013:

99) 
Beberapa penelitian telah dilakukan tentang penggunaan model klarifikasi nilai (VCT) untuk meningkatkan bidang emosional dalam pendidikan. Sebagian besar penelitian tersebut membahas tentang hasil belajar afektif siswa sekolah dasar (Seran dan Cahyani, 2018), peningkatan pemahaman tentang nilai pada siswa sekolah dasar (Azis, 2018), pembelajaran berbasis nilai (Ekasari, 2017), dan peningkatan berpikir kreatif sebagai upaya internalisasi pendidikan karakter (Utami, Novia dan Agustina 2012), internalisasi nilai-nilai kearifan lokal (Asmi, 2018), pengembangan social skill siswa (Rachmadiyanti dan Rochani, 2017) dan peran higher order thinking skills di era society 5.0 (Agustina dan Wibawa, 2019).

Beberapa dari studi ini diterapkan secara luas untuk siswa sekolah dasar dan jarang sekali untuk siswa sekolah menengah atas. Oleh karena itu, peneliti tertarik untuk meneliti di sekolah mengah atas karena melihat berbagai masalah yang ada diatas dengan judul Penerapan Model Pembelajaran VCT (Value Clarification Technique) dalam Pembelajaran Menulis Argumentasi di Era Society 5.0. Peneliti berharap melalui penerapan model pembelajaran value clarification technique untuk siswa SMA ini semoga Judapat menanamkan peserta didik Inuntuk berpikir lebih kritis tentang apa yang terjadi di dunia luar, sehingga dapat menghadapi transisi antara Revolusi Industri 4.0 dan Society 5.0.

\section{METODE}

Metode penelitian yang digunakan dalam penelitian ini adalah metode eksperimental. Bentuk penelitian yang digunakan dalam penelitian ini adalah quasi-eksperimental design dengan menggunakan pretest-posttest control group design. Penelitian ini dilaksanakan di SMA Negeri 1 Cisarua pada tahun ajaran 2020/2021. Populasi penelitian ini adalah seluruh siswa SMA Negeri 1 Cisarua yang berjumlah 30 peserta didik. Dalam penelitian ini, pengambilan sampel non-probabilitas dengan menggunakan teknik sampel jenuh digunakan untuk menentukan sampel, yaitu semua anggota populasi digunakan sebagai sampel.

Selain itu, data yang diperoleh mengenai penerapan model pembelajaran VCT yaitu melalui lembar observasi guru, memperoleh data prestasi belajar siswa melalui tabel observasi prestasi belajar afektif dan psikomotirik peserta didik, melakukan pengukuran awal dan pengukuran akhir peserta didik dan memperoleh tanggapan mengenai model pembelajaran yang digunakan peserta didik melalui angket survei. Selain itu, dilakukan uji prasyarat yaitu uji normalitas dan uji homogenitas untuk mengetahui normalitas dan homogenitas data yang digunakan. Setelah data normal dan homogen maka dilakukan uji hipotesis yaitu uji t untuk menjawab uji hipotesis dalam penelitian.

\section{HASIL DAN PEMBAHASAN}

nich Penelitian ini dilakukan untuk mengetahui keefektifan penerapan model VCT (Value Clarification Technique) dalam pembelajaran menulis argumentasi. Model tersebut telah dianalisis oleh praktisi yaitu guru bahasa Indonesia di SMA Negeri 1 Cisarua.

\section{Analisis Hasil Belajar Afektif Peserta Didik}

Penerapan model pembelajaran VCT (Value Clarification Technique) 
berdampak baik terhadap peningkatan hasil belajar afektif dalam pembelajaran menulis argumen. Dari hasil observasi siswa di kelas sampel terlihat bahwa terdapat perbedaan antara siswa yang diajarkan dengan menggunakan model VCT dengan siswa yang diajarkan dengan menggunakan model konvensional. Perbedaan hasil belajar siswa antara kelas eksperimen dan kelompok kontrol juga dapat dilihat pada tabel 1.1 berikut.

Tabel 1.1

Perbedaan Hasil Belajar Afektif

Menulis Argumentasi Siswa Kelas

Eksperimen dan Peserta Didik Kelas Kontrol pada Pengamatan Akhir

\begin{tabular}{|c|c|c|c|}
\hline Kelas & Maksimal & Minimal & $\begin{array}{c}\text { Rata- } \\
\text { rata }\end{array}$ \\
\hline Eksperimen & 20 & 17 & 18,667 \\
\hline Kontrol & 20 & 12 & 15,708 \\
\hline
\end{tabular}

Dari rata-rata skor hasil observasi akhir siswa kelas eksperimen terlihat bahwa selisih antara kelas eksperimen dan kelompok kontrol adalah 18,667, skor tertinggi 20, dan skor terendah 17, sedangkan kelompok kontrol memiliki skor rata-rata 15,708 dan skor tertinggi 20, dan skor terendah adalah 12 . Berdasarkan skor tersebut, tes Kolmogrov Smirnov versi SPSS 21 digunakan untuk menguji normalitas pada observasi akhir kelas eksperimen dan kontrol. Hasil yang diperoleh adalah 0,134> nilai signifikansi pada kelas eksperimen dan kontrol adalah 0,05. $0,381>$ nilai signifikannya 0,05 .

Berdasarkan hasil tersebut, sesuai standar nilai signifikan normalitas yang diperoleh dengan menggunakan uji Kolmogrove Smirnov dapat disimpulkan bahwa data observasi akhir kelompok eksperimen dan kontrol berdistribusi normal. Selain itu, peneliti menggunakan uji $\mathrm{F}$ versi SPSS 21 untuk menguji homogenitas kelompok eksperimen dan kelompok kontrol selama observasi akhir dengan hasil nilai signifikansi 0,189 adalah 0,05 $(5 \%)$. Berdasarkan hasil ini, menurut standar ketentuan nilai signifikasn $F$ SPSS 21, dapat disimpulkan bahwa data observasi akhir kelas eksperimen dan kelas kontrol adalah homogen. Perbedaan hasil belajar siswa pada pengamatan akhir antara kelas eksperimen dan kelas kontrol dapat dilihat pada tabel 1.2 berikut.

\section{Tabel 1.2}

\section{Perbedaan Hasil Belajar Afektif \\ Kelas Eksperimen dan Kelas Kontrol pada Pengukuran Akhir}

\begin{tabular}{|c|c|c|c|c|c|}
\hline Posttest & Dk & thitung & tabel & $\alpha$ & Ket. \\
\hline Eksperimen & \multirow{2}{*}{46} & 2,910 & 2,013 & 0,05 & $\begin{array}{c}\mathrm{H}_{\mathrm{a}} \\
\text { diterima } \\
\text { Kantrol } \mathrm{H}_{\mathrm{o}} \\
\text { ditolak }\end{array}$ \\
\hline
\end{tabular}

Dapat dilihat pada Tabel 1.2, ttabel kelas eksperimen dan kelas kontrol adalah 2,910, dan t-tabel dengan taraf signifikansi $5 \%$ total dk 46 adalah 2,013. Karena $t_{\text {hitung }}>t_{\text {tabel }}$ maka menurut standar pengujian dapat disimpulkan bahwa Ho ditolak dan $\mathrm{Ha}$ diterima: Berdasarkan standar pengujian dapat disimpulkan bahwa pada hasil observasi akhir terdapat perbedaan yang signifikan antara kelas eksperimen dan kelas kontrol. Dapat dilihat dari uraian tersebut bahwa berdasarkan nilai yang diperoleh, nilai pengukuran akhir dari kelas eksperimen dan kelompok kontrol sangat signifikan.

Menurut pengamatan peneliti selama proses pembelajaran, penerapan metode pembelajaran VCT (Value 
Clarification Technique) dalam proses pembelajaran pada kelas eksperimen memiliki peran yang sangat penting, sehingga memungkinkan peserta didik untuk dapat memanfaatkan dan mengimplementasikannya dalam kehidupan sehari-hari. Kemampuan guru dengan menggunakan model VCT dalam pembelajaran menulis argumentasi membuat peserta didik untuk mampu memutuskan, mengkomunikasikan, dan mengungkapkan pikiran, keyakinan, nilai dan perasaannya. Hal ini seperti yang dikatakan Simon terkait salah satu manfaat metode klarifikasi nilai (dalam Adisusilo, 2013). Melalui metode pembelajaran VCT ini peserta didik dilatih untuk memilih dan menentukan nilai, sehingga memiliki sebuah pendirian.

\section{Analisis Hasil Belajar Psikomotorik Peserta Didik}

Penerapan model pembelajaran VCT (Value Clarifiction Technique) memiliki pengaruh yang sangat baik dalam meningkatkan hasil belajar afektif dan psikomotorik dalam pembelajaran menulis argumentasi. Hal ini terlihat dari hasil observasi peserta didik pada kelas sampel bahwa terdapat perbedaan antara peserta didik yang menggunakan model VCT lu unfuk pembelajaran dengan peserta didik yang menggunakan model konvensional untuk pembelajaran menulis argumentasi. Perbedaan hasil belajar antara kelas eksperimen dan kelompok kontrol juga dapat dilihat pada tabel 1.3 berikut.

\section{Tabel 1.3}

Perbedaan Hasil Belajar

Psikomotorik Menulis Argumentasi

Peserta Didik Kelas Eksperimen dan

Peserta Didik Kelas Kontrol pada Pengamatan Akhir

\begin{tabular}{|c|c|c|c|}
\hline Kelas & Maksimal & Minimal & $\begin{array}{c}\text { Rata- } \\
\text { rata }\end{array}$ \\
\hline Eksperimen & 20 & 16 & 17,536 \\
\hline Kontrol & 20 & 10 & 12,112 \\
\hline
\end{tabular}

Dari rata-rata hasil observasi akhir siswa kelas eksperimen terlihat bahwa selisih antara kelas eksperimen dan kelas kontrol adalah 17.536, nilai tertinggi 20 , nilai terendah 16 , nilai observasi rata-rata kelompok kontrol 12.112, nilai tertinggi 20 , dan nilai terendah adalah 10. Berdasarkan skor tersebut, tes SPSS 21 versi Kolmogrov Smirnov digunakan untuk menguji normalitas dari hasil observasi akhir kelompok eksperimen dan kelompok kontrol. Hasil yang diperoleh sebesar $0,114>$ nilai signifikansi sebesar 0,05 pada kelas eksperimen dan pada kelas kontrol adalah $0,312>$ nilai signifikansinya 0,05 .

zan Bal Berdasarkan hasil tersebut, sesuai cstandar nilai signifikan normalitas yang diperoleh dengan menggunakan uji Kolmogrov Smirnov, dapat disimpulkan bahwa data observasi akhir kelas eksperimen dan kelas kontrol berdistribusi normal. Dengan menggunakan SPSS 21 versi dalam melakukan uji $F$ untuk menguji homogenitas kelompok eksperimen dan kelompok kontrol pada observasi akhir. Hasil yang diperoleh Sig. sebesar 
0,179> nilai signifikansi sebesar 0,05 (5\%). Berdasarkan hasil tersebut, dengan standar nilai signifikan $\mathrm{F}$ pada SPSS versi 21 dapat disimpulkan bahwa data kelas eksperimen dan data observasi akhir kelas kontrol adalah homogen. Perbedaan hasil belajar antara kelas eksperimen dan kelompok kontrol dapat dilihat pada Tabel 1.4 berikut ini.

\section{Tabel 1.4}

Perbedaan Hasil Belajar Afektif Kelas Eksperimen dan Kelas Kontrol pada Pengukuran Akhir menentukan suatu nilai yang dianggap baik dalam menghadapi suatu persoalan melalui proses menganalisis nilai yang sudah ada dan tertanam dalam diri siswa. Sedangkan pada kelas kontrol hanya mengunakan pembelajaran konvensional, yaitu dengan menggunakan metode ceramah dan pengerjaan tugas secara individu.

Setelah diamati pada pengamatan akhir, dari hasil uji t tersebut dapat diketahui bahwa ada perbedaan yang signifikan antara kelas eksperimen dan kelas kontrol pada pengukuran akhir, kesimpulan tersebut diperoleh peneliti

\begin{tabular}{|c|c|c|c|c|r|}
\hline Posttest & Dk & $\mathrm{t}_{\text {hitung }}$ & $\mathrm{t}_{\text {tabel }}$ & $\alpha$ & Ket \\
\cline { 1 - 4 } Eksperimen & \multirow{2}{*}{61} & 3,714 & 2000 & 0,05 & $\begin{array}{r}\mathrm{H}_{\mathrm{a}} \text { dite } \\
\text { dan } \mathrm{H}_{\mathrm{o}} \mathrm{d}\end{array}$ \\
\cline { 1 - 3 } Kontrol & & & & & \\
\hline
\end{tabular}

Berdasarkan tabel 1.4 dapat dilihat bahwa $t_{\text {hitung }}$ kelas eksperimen dan kelas kontrol adalah 3,714 sementara $t_{\text {tabel }}$ pada taraf signifikansi $5 \%$ dengan $\mathrm{dk}$ berjumlah 61 adalah 2,000. Karena thitung $>t_{\text {tabel, }}$, sesuai dengan kriteria pengujian maka dapat disimpulkan bahwa Ho ditolak dan Ha diterima. Sesuai dengan kreteria pengujian maka dapat disimpulkan bahwa terdapat perbedaan yang signifikan antara kelas eksperimen dan kelas kontrol pada pengamatan akhir.

Dari uraian tersebut, dapat kit ketahui bahwa pengukuran akhircpada kelas eksperimen dan kelas kontrol berdasarkan nilai yang diperoleh yaitu sangat signifikan. Hal ini disebabkan karena adanya perlakuan yang diberikan pada kelas eksperimen yaitu pembelajaran dengan menggunakan model VCT (Value Clarification Technique) atau sering disingkat VCT merupakan teknik pengajaran untuk membantu siswa dalam mencari dan
Ket karna signifikansi $t_{\text {hitung }}<t_{\text {tabel, }}$, sesuai Haditermagan kreteria pengujian maka Ho diditalak dan $\mathrm{Ha}$ diterima maka berdasarkan teori signifikansi yaitu taraf signifikansi tertinggi adalah 5\%, dengan ini peneliti menyimpulkan bahwa ada perbedaan yang sangat signifikan antara kelas eksperimen dan kelas kontrol pada pengamatan akhir, selain itu kesimpulan dari pembahasan pengamatan eksperimen dan kontrol tersebut juga sesuai dengan kajian penelitian yang relevan dari Wiratama, Murda, dan Partadjaya (2012) yang hasil penelitiannya menunjukkan bahwa terdapat perbedaan hasil belajar afektif yang signifikan antara kelas yang menggunakan model VCT (Value Clarifiction Technique) dan kelas kontroleroyang menggunakan model

\section{Respon Peserta Didik terkait Model Pembelajaran VCT (Value Clarification Technique)}

Value Clarification Technique atau sering disingkat VCT merupakan teknik pengajaran untuk membantu siswa dalam mencari dan menentukan suatu nilai yang dianggap baik dalam menghadapi suatu persoalan melalui pembelajar konvensional. 
proses menganalisis nilai yang sudah ada dan tertanam dalam diri siswa. Berikut tabel hasil respon siswa.

\section{Tabel 1.5}

\section{Hasil Angket Respon Siswa}

\begin{tabular}{|c|c|c|}
\hline Skor Total & Presentase & Kategori \\
\hline 1885 & $94,25 \%$ & Sangat Tinggi \\
\hline
\end{tabular}

Dari tabel 1.5 dapat diketahuai respon siswa dengan diterapkan model VCT (Value Clarifiction Technique) berdasarkan hasil peryataan persetujuan siswa dari hasil angket diperoleh skor total 1885 dengan hasil persentase akhir 94,25\% dari persentase $100 \%$ yang diharapkan. Persentase respon siswa terhadap model ini belum mencapai $100 \%$ dikarenakan ada beberapa siswa yang mungkin kurang menyukai model VCT (Value Clarifiction Technique), beberapa siswa ini kurang suka dengan model yang diterapkan diperkirakan karena kurang aktifnya siswa ini dalam proses pembelajaran dan tidak mau bergabung belajar bersama temannya. Berdasarkan persentase respon yang ada dapat disimpulkan penilaian siswa terhadap penggunaan model VCT (Value Clarifiction Technique) dalam proses belajar mengajar masuk kategori sangat tinggi.

Hal ini di karenakan Paalam pembelajaran menggunakan model $\mathrm{VCT}$ (Value Clarifiction Technique) siswa terlibat aktif dalam proses belajar mengajar dan dapat melakukan interaksi dengan temannya serta dapat saling menghormati dan menghargai pendapat yang lain, dapat praktek secara lansung sehingga siswa dapat pengalaman yang nyata dan juga dalam proses pembelajaran menggunakan model ini siswa dapat belajar tanpa tekanan dan dapat merasa santai dan bergembira. Hasil penelitian ini sejalan dengan penelitian terdahulu oleh Asmi (2018) menyatakan bahwa pembelajaran dengan model VCT (Value Clarifiction Technique) mendapat respon yang positif dari siswa, hal itu menunjukan bahwa siswa menyukai pembelajaran dengan menggunakan VCT (Value Clarifiction Technique).

\section{SIMPULAN}

Berdasarkan analisis data yang telah dilakukan dalam penelitian ini, maka dapat ditarik kesimpulan sebagai berikut.

1. Tidak terdapat perbedaan hasil belajar afektif dan psikomotorik yang signifikan pengukuran awal antara kelas eksperimen dan kelas kontrol, hal ini terlihat dari hasil belajar afektif rata-rata pengamatan awal kelas ekperimen adalah 14,500 dan rata-rata pengamatan awal kelas kontrol 13,292, hasil belajar psikomotorik rata-rata pengamatan awal kelas ekperimen adalah 12,300 dan rata-rata pengamatan awal kelas kontrol 11,190. Hasil analisis menunjukkan bahwa nilai $t_{\text {hitung }}$ lebih kecil dari nilai $t_{\text {tabel }}(1,102<1,767)$ yang artinya tidak terdapat perbedaan yang signifikan.

Terdapat perbedaan hasil belajar afektif menulis argumentasi yang signifikan dengan pengukuran akhir antara kelas eksperimen dan kelas kontrol terlihat dari hasil rata-rata pengukuran awal kelas eksperimen adalah 18,667 dan rata-rata pengukuran awal kelas kontrol adalah 15,708. Hasil analisis menunjukan bahwa nilai $t_{\text {hitung }}$ lebih kecil dari $t_{\text {tabel }}(2,910>2,013)$ yang artinya terdapat perbedaan yang signifikan. 
3. Terdapat perbedaan hasil belajar psikomotori menulis argumentasi yang signifikan dengan pengukuran akhir antara kelas eksperimen dan kelas kontrol terlihat dari hasil ratarata pengukuran awal kelas eksperimen adalah 17,536 dan ratarata pengukuran awal kelas kontrol adalah 12,112. Hasil analisis menunjukan bahwa nilai $t_{\text {hitung }}$ lebih kecil dari $t_{\text {tabel }}(3,714>2,000)$ yang artinya terdapat perbedaan yang signifikan.

4. Respon siswa terhadap model pembelajaran VCT (Value Clarifiction Technique) dapat dikatakan sangat baik, dilihat dari hasil perhitungan secara keseluruhan adalah sebesar 94,25\%. Berkaitan dengan keseluruhan hasil penelitian yang telah dilakukansaran yang disampaikan oleh peneliti Bagi Guru yaitu Topik pembelajaran harus menarik dan sesuai dengan model pembelajaran serta sesuai dengan pengalaman siswa agar siswa ikut bagian secara aktif dalam penerapan model pembelajaran VCT (Value Clarifiction Technique), serta nilai yang ingin ditanamkan dapat tercapai.

Model pembelajaran berbasis nilai melalui VCT dalam pembelajaran menulis argumentasi, pilihan lain dapat menjadi salah satu pilihan bagi guru bahasa Indonesia untuk mencapai tujuan pembelajaran bahasa Indonesia khususnya pada kegiatan menulis argumentasi. Selain itu, di tengah permasalahan yang ada dalam pembelajaran bahasa Indonesia khususnya yang berkaitan dengan kegiatan menulis argumentasi bagi siswa, nampaknya model pembelajaran ini sangat cocok untuk mengatasi permasalahan tersebut. Selain itu, langkah-langkah yang diberikan oleh model pembelajaran ini dapat memandu peserta didik untuk memperoleh hasil belajar bahasa Indonesia khususnya dalam kegiatan menulis argumentasi yang lebih seimbang. Keseimbangan masalahnya terletak pada integrasi kognisi, emosi dan psikomotorik.

\section{DAFTAR PUSTAKA}

Adisusilo, S. 2013. Pembelajaran Nilai-Karakter: Konstruktivisme dan VCT Sebagai Inovasi Pendekatan Pembelajaran Afektif. Jakarta: Rajawali Pers.

Agustina dan Wibawa. 2019. Peran Pendidikan Berbasis Higher Order Thinking Skills (Hots) pada Tingkat Sekolah Menengah Pertama di Era Society 5.0 sebagai Penentu Kemajuan Bangsa Indonesia. Equilibrium, Volume 7, Nomor 2, Juli 2019

Akhadiah, Sabarti, Maidar G. Arsjad, dan Sakura H. Ridwan 1999. Pembinaan Kemampuan Menulis Bahasa Indonesia. Jakarta: Erlangga.

Asmi, Rol, A. 2018. Media Pembelajaran dalam Internalisasi Nilai-Nilai Kearifan Lokal Berbasis VCT (Value Clarification Technique) pada Pembelajaran Sejarah. Jurnal Candrasangkala Vol 4 , No. 1 (Mei 2018). Palembang: Universitas Sriwijaya. Azis, A. 2018. Penanaman Sikap Sosial pada Pembelajaran PKn di Sekolah Dasar. Jurnal Panrita, 12(1), 1-9.

Daryanto, Karim, S. 2017. Pembelajaran abad 21. Yogyakarta: Penerbit Gava Media.

Ekasari, Nur, P. 2017. Pembelajaran Berbasis Nilai pada Matapelajaran Sejarah Melalui 
Model Vct (Value Clarification Technique). Jurnal Sejarah dan Budaya, Tahun Kesebelas, Nomor 2, Desember 2017. Malang: Universitas Malang

Etin Solihatin. 2014. Strategi Pembelajaran PPKN. Jakarta: PT Bumi Aksara.

Hernowo. 2001. Mengikat Makna. Bandung: Kaifa.

Kemendikbud. 2016. Permendikbud Nomor 22 Tahun 2016 Tentang Standar Proses Pendidikan Dan Menengah. Jakarta: Kemendikbud

Nasia, S., Saneba, B., dan Hasdin. 2014. Meningkatkan Kerjasama Siswa Pada Pembelajaran PKn Melalui Value Clarification Technique (VCT) di Kelas IV GKLB Sabang, 2 (3), 63-77.

Nurgiyantoro, B. 2001. Penilaian dalam Pengajaran Bahasa dan Sastra. Yogyakarta: BPFE Yogyakarta.

Purnamasari, J., Yunisrul, dan Desyandri. 2018. Peningkatan Pembelajaran Tematik dengan Pendekatan Scaintific di Kelas I SDN 15 Ulu Gadut, Kota Padang. Ejournal Pembelajaran Inovasi: Jurnal Ilmiah Pendidikan Dasar, 6 (1), 11-24. Retrieved from http://ejournal.unp.ac.id/students/i ndex.php/pgsd/article/view/3906/2 485

Rachmadiyanti dan Rochani. 2017. Pengembangan Social Skill Siswa Sekolah Dasar melalui Teknik Pembelajaran VCT (Value Clarification Technique).

Dwijacendekia Jurnal Riset Pedagogik 1 (2)(2017) 70-78.

Rejeki, Sri dan Ganes Gunansyah. 2015. Penggunaan Model Pembelajaran Value Clarifiation Technique (VCT) untuk
Meningkatkan Civic Disposition Pada Mata Pelajaran Pkn Siswa Kelas V SDN Kalasan 1 Sleman. April,1-9.

Sanjaya, Wina. 2006. Strategi Pembelajaran Berorientasi Standar Proses Pendidikan. Jakarta: Kencana Prenada Media Grup.

Seran dan Cahyani. 2018. Penerapan Model Pembelajaran Value Clarification Technique (VCT) Terhadap Hasil Belajar Afektif Pelajaran IPS. Jurnal Pekan Vol. 3 No. 1 Edisi April 2018.

Suriasumantri, Jujun, S. 1996. Filsafat Ilmu: Sebuah Pengantar Populer. Jakarta: Pustaka Sinar Harapan.

Taniredja, dkk. 2011. Model-Model Pembelajaran Inovatif. Bandung: Alfabeta.

UNESCO. 2003. Monitoring and Evaluation Guidance for School Health Programs: Thematic Indicators Supporting FRESH (Focusing Resourcesand Effective School Health). Unesco: Who.

Utami, Novia dan Agustina. 2012. Aplikasi Model VCT (Value Clarification Technique) Berbasis Local Wisdom sebagai Upaya Internalisasi Pendidikan Karakter untuk Meningkatkan Kreativitas Berpikir dan Hasil Belajar Biologi Siswa. Seminar Nasional IX Pendidikan Biologi Fkip UNS.

Widyamertaya, A dan Veronica Sudiati. 1997. Dasar-dasar menulis karya ilmiah. Jakarta: Grasindo. 